\title{
IES
}

\section{GIVING CHILDREN A BETTER START: Pre-SCHOOL ATTENDANCE AND SCHOOL-AgE PROFILES}

Samuel Berlinksi Sebastian Galiani Marco Manacorda 


\title{
Giving Children a Better Start: Preschool Attendance and School-Age Profiles
}

\author{
Samuel Berlinski ${ }^{*}$ \\ University College London \\ and Institute for Fiscal Studies
}

\author{
Sebastian Galiani \\ Washington University \\ in St. Louis
}

\author{
Marco Manacorda \\ Queen Mary University of London, \\ CEP (LSE) and CEPR
}

This Version: August 14, 2006

\begin{abstract}
We study the effect of pre-primary education on children's subsequent school outcomes by exploiting a unique feature of the Uruguayan household survey $(\mathrm{ECH})$ that collects retrospective information on preschool attendance. A rapid expansion in the supply of pre-primary places over the last decade generates sufficient variation in the data to warrant identification. Using a within household estimator that only exploits differences in exposure across siblings, we find small gains from preschool attendance at early ages that magnify as children grow up. By age 16, children that attended preschool have accumulated more than 1 extra year of education and are 27 percentage points more likely to be in school compared to their siblings with no preschool education. We speculate that early grade repetition harms subsequent school progression and that pre-primary education appears as a successful policy option to prevent early grade failure and its long lasting consequences.
\end{abstract}

\footnotetext{
* Samuel Berlinski, Department of Economics, University College London, Gower Street, London WC1E 6BT, UK, s.berlinski@ucl.ac.uk. Sebastian Galiani, Department of Economics, Washington University in St Louis, Campus Box 1208, St Louis, MO 63130-4899, US, galiani@economics.wustl.edu. Marco Manacorda, CEP, London School of Economics, Houghton Street WC2A 2AE, London, UK, m.manacorda@lse.ac.uk. We are grateful to Andres Peri, Emiliana Vegas, and Andrea Vigorito for helpful comments.
} 


\section{Introduction}

This paper estimates the effect of pre-primary education on school stay-on rates and levels of completed education among individuals aged 7-16. We exploit a rather unique feature of the Uruguayan Encuesta Continua de Hogares (ECH) for the years 2001-2005 that collects retrospective information on the number of years of preschool attended. In order to control for unobserved household characteristics that are common to all children in the household and that might affect simultaneously exposure to pre-primary education and school progression we use a within household estimator that only exploits variability in the outcome and treatment variables across siblings. A major expansion in the provision of public pre-primary education in Uruguay over the last decade that led to an acceleration in preschool attendance among subsequent birth cohorts and that mainly affected children from more disadvantaged backgrounds generates sufficient variation in exposure to preschool across siblings to warrant identification.

We find a significant positive effect of preschool attendance on completed years of education. This works both through a fall in retention rates since the very early school years (from age 8 onwards) and a reduction in drop out among teenagers (from age 13 onwards). The gains from having attended preschool increase as children grow older, so that exposure to pre-primary education leads to gradually diverging paths in school performance between treated and untreated children. We speculate that early grade retention increases the incentives for early drop out and raises the probability of grade failure later in the school life and that pre-primary education appears as a successful policy to prevent early school failure and its long lasting consequences.

In poor countries, a large share of the population is excluded from the education system already at an early age and well before completion of the compulsory schooling cycle. Exclusion from the school system encompasses in varying combinations failure to enroll, late entry, intermittent and irregular attendance, high retention rates and eventually early drop out (UNESCO, 2005).

In this context, early exposure to the school system appears as a possibly successful policy option. What makes pre-primary school different from primary school is that this is not generally 
conceived as an academic experience and children are not evaluated based on their performance. In Uruguay, as elsewhere, grade retention in preschool is not an option (while it is in primary school), and children progress to the primary school cycle when they turn compulsory schooling age independently of their performance. This creates an environment for children to learn and socialize without some of the potentially distorted incentives linked to a formal evaluation system (such as competition among students or teachers) and guarantees a common starting ground for children from rather heterogeneous backgrounds. If early success in school is a good predictor of later school performance, and if preschool attendance strengthens early school outcomes particularly among children with worse school potential, then early interventions might yield high returns.

A large body of literature in neuroscience, psychology and cognition makes the case for early childhood interventions. Research has established that learning is easier in early childhood than later in life, and that nutrition and cognitive stimulation early in life are critical for long-term skill development (see, among others, Bransford, 1979; Shonkoff and Phillips, 2000; Shore, 1997 and Sternberg, 1985). Thus, learning starts well before the day children enter primary school. The process of cognitive development starts at home and it is expected that pre-primary education facilitates this process by planning and providing systematic activities for children. Indeed, there is a widespread belief among educators that the benefits of pre-primary education are carried over to primary school. In particular, teachers identify lack of academic skills as one of the most common obstacles children face when they enter school (see, Rimm-Kaufman et al., 2000). Also, they perceive preschool education as facilitating the process of socialization and self-control necessary to make the most of classroom learning (see Currie, 2001).

In the economic literature, Carneiro and Heckman (2002) and Cunha et al. (2006) make a strong case for early investment in education. They suggest that the return to the investment in human capital declines exponentially during the life cycle, being the highest earlier in life. Not only the earlier the investment, the longer the time available for recovering it. In addition, some inputs are 
likely to have low returns when employed later in life (e.g., it is hard to achieve any gains in IQ after a certain age) and potential complementarities arise among different types of investment, implying that higher levels of past inputs (and therefore of current human capital) yield higher returns to current investment in human capital.

While there is substantial empirical evidence that intensive early education interventions targeted specifically to disadvantaged children lead to significant benefits (see, among others, Lee et al. 1990, Barnett, 1993, Barnett, 1995, Currie and Thomas 1995, Reynolds 1998, Karoly et al., 1998, Danzinger and Waldfogel, 2000; Currie, 2001, Garces et al. 2002, Blau and Currie 2004, and Schweinhart 2005), much less is known about the benefits of expanding pre-primary education for the population as a whole. Cascio (2004) finds that the expansion of kindergarten financing in the late 60s and early 70s in the Southern and Western States of the US reduced subsequent grade repetition relative to Northern Sates. Using data from the Early Childhood Longitudinal Study, Magnuson et al. (2005) find that pre-primary education in the US is associated with higher reading and mathematics skills at primary school entry, but that these effects dissipate by the end of first grade. They also find that pre-primary education in the US is associated with higher levels of behavioral problems, especially when pre-kindergartens are not located in public schools. Exploiting a natural experiment in Argentina, Berlinski et al. (2006) find a positive effect of preprimary school attendance on third grade standardized Spanish and Mathematics test scores. They also find that pre-primary school attendance positively affects primary school pupils' behavioral outcomes such as attention, effort, class participation, and discipline.

A major challenge in identifying the causal effect of pre-primary school attendance on later school outcomes is non-random selection into early education. Positive selection, whereby parents whose children attend pre-primary school possess characteristics that promote better school performance, would result in a spurious positive correlation between preschool and later academic outcomes. Indeed, since children are not randomly selected into pre-primary education, selection 
based on parental heterogeneity is most likely to be non-ignorable in identifying the effect of preprimary education on subsequent school progression. In order to circumvent this problem, in this paper we control for unobserved determinants of school progression that are correlated with selection into pre-primary education by conditioning on household fixed effects in the regressions. This approach is similar to the one followed by Currie and Thomas (1995), Currie and Thomas (1999) and Garces, et al. (2002) who examined the impact of Head Start on school performance using longitudinal data.

The rest of the paper is organized as follows. Section 1 provides background information on the Uruguayan school system and the educational reform of the 1990s that led to a rapid acceleration in preschool enrollment rates. Section 2 describes the data. Section 3 lays the empirical strategy and discusses the identification strategy. Section 4 presents the regression results and Section 5 finally concludes.

\section{Background}

Uruguay is a relatively small country (176.261 sq. km, to get a sense around one and half time NY State) and one of the richest (GDP per capita was US\$ 4,800 in 2005, IMF 2005) and less populated countries in Latin America (population is around 3.2 million, compared to a population in NY State of around 19.3 million). Although Uruguay is an early starter in the process of development, over the second half of last century the country has grown at a slow rate. While per capita GDP in 1870 was approximately equal to the contemporaneous per capita income in the USA, in 1920 this figure was about $50 \%$ and by the end of the last century this was around 30\% (Maddison, 2004). Nowadays the share of population below the poverty line is about 21\% (CIA, 2005).

Uruguay boasts a long tradition of social inclusion and publicly provided education. By the beginning of last century, Uruguay had achieved levels of economic and social progress comparable to some European countries. Primary schooling was made compulsory in 1877 and universal 
primary schooling was achieved in the 1950s. The literacy rate is among the highest in the region (97\% among men and 98\% among women).

Even if Uruguay still ranks high in terms of its educational outcomes compared to the rest of Latin America, its education system is not free of problems. Over the last decades growth in educational attainment of the population has been rather modest. From 1960 to 2000 for example, while average years of education in the population over 25 in the USA have risen by around 4.5 years (from 8.7 to 12.2), growth in Uruguay has been in the order of 2.1 years (from 5.1 to 7.2 ) (Barro and Lee, 2001).

Two of the most notable inefficiencies of the system are widespread grade retention and early drop out, the two being correlated (Manacorda, 2006). Although grade retention is a phenomenon common to other Latin American countries (see among others Urquiola and Calderon, 2004), data from UNESCO (2005) show that Uruguay is well above the continent average. Data from a specific education module administered in conjunction with the National Household Survey (Encuesta Continua de Hogares) of 2001 illustrates a long delay in the transition through the primary school system due to widespread grade retention. Despite normal entry into school (average age at entry is 5.82 versus a theoretical entry age of 6), and universal enrollment in primary school, by age 12 about $54 \%$ of individuals still have not completed primary education (sixth grade). Grade repetition affects $25 \%$ of primary school students and about $20 \%$ of those in secondary school. Repetition is largely concentrated in the first years of each school cycle and disproportionately affects some individuals. On average repeaters lose around 1.5 years in primary school and 1.2 years in secondary school. In the age group 24-29 around 20\% of individuals declare never having started junior high school. Among those who started this school cycle around 16\% declare not having completed it. Data in ANEP (2005) show markedly more pronounced repetition rates among children from more disadvantaged backgrounds. Based on a socio-cultural indicator of schools, 
children in the bottom quintile of the distribution of that indicator are around three times more likely to repeat than children in schools in the top quintile.

In recognition of these problems, in the mid-1990s, Uruguay embarked in a major educational reform (ANEP, 2000). One of the main objectives of the reform was to achieve universal preprimary education for 4 and 5 years old ${ }^{1}$. Until then, compulsory education included primary education (educación primaria, ages 6-11), and junior high school (ciclo basico, ages 12-14). Public provision of education also extended to pre-primary education (educación incial, ages 3-5), Senior High School and Tertiary education, although none of these was compulsory. The motivation for this reform was at least twofold. First, this was meant to achieve an increase in the number of years of compulsory schooling without rising minimum compulsory schooling age. This was deemed necessary due to the unsatisfactory performance of the Uruguayan labor market and the widespread belief that such bad performance was partly due to the lack of skills of its workforce. Rather than increasing the number of compulsory school years by raising school leaving age, the government opted to achieve this objective by lowering entry age. This appeared the most viable policy option given the inability of the system to retain a large proportion of teenagers. Second, this program hoped to ease children's insertion into and transition through the primary school system, by providing them with some basic foundations before the start of the primary cycle and socializing them (and their parents) to school from an early age. ${ }^{2}$ The hope was that this policy would reduce the high incidence of repetition among primary school children, hence making the transition through the primary school cycle speedier and reducing in turn the incentive for early drop out.

The lack of teaching infrastructures was a major constraint to a further expansion of the system and for this reason, in 1995 ANEP (Administration Nacional de Educación Pública), the government agency in charge of public education, started an ambitious building plan which aimed at expanding preschool provision in public primary schools. By 1999, 414 new classrooms had been

\footnotetext{
${ }^{1}$ It is worth noting that the minimum level of compulsory schooling did not change during this period.
} 
built (or made available via refurbishment). It is estimated than another 370 classrooms were made available between 1999 and 2002. This policy was accompanied by a massive increase in the number of preschool teachers.

Based on government documents (ANEP, 2005), the reform was very successful at least as far as children incorporation into the system was concerned. In the face of a substantial stability in public pre-primary enrollment between 1992 and 1995 (with enrollment rising from 48,107 to 49,618 pupils) between 1995 and 2004 enrollment in public preschools grew from 49,618 to 87,237 pupils, a rise of $76 \%$ over 9 years.

The infrastructure expansion was apparently extremely successful in incorporating children from less disadvantaged backgrounds. According to data in ANEP (2005), while in 1991 attendance rates of 4 years old in households in the lowest quintile of the income distribution was in the order of $20 \%$, by 2002 this figure was in the order of $60 \%$.

\section{Data and basic evidence}

For the purpose of the empirical analysis we use micro data from the Uruguayan Encuesta Continua de Hogares (ECH). This is a representative household survey run throughout the year by the National Statistical Office (INE: Instituto Nacional de Estadística) that covers around 18,000 households each year in urban Uruguay. The survey collects data on the socio-demographic characteristics of the households and school attendance and highest grade completed for all individuals.

Starting from 2001 the ECH provides retrospective information on the number of years of preprimary education attended. We can hence use data from 2001 to 2005 to relate current school performance to past preschool attendance. One limitation of the data is that retrospective data on

\footnotetext{
${ }^{2}$ The preschool curriculum is explicitly designed with the objectives of promoting both a child's "intellectual and communication abilities" and his "biological, psychological and social development" (ANEP, 1997).
} 
either past repetition or on school entry age are not available. The data also do not distinguish between the type of pre-primary school attended, whether public or private.

We restrict our analysis to a sample of individuals aged 7-16 that live in two parent families where all children are children of the head of the household. We restrict the sample to children of the head of the household due to the key role that the within siblings differences strategy plays in the identification of the parameter of interest. We restrict to children aged 7 or older because some children aged 6 are still in preschool age during some survey months. We also exclude children aged 17 or older since by that age some of them (notably girls) have already moved out of their parental home and this is possibly correlated with preschool exposure.

In Table 1, we define the variables used in the paper and a set of descriptive statistics. We have a sample of 25,696 children over five years, $90 \%$ of them attended at least one year of preschool with an average of 1.74 years of preschool. Average age is 11.55 while the average years of education completed after preschool is 5.03. Therefore, on average children have completed around half a year of education less than one would expect if they had all enrolled at age 6, progressed regularly and stayed on until age 16 (in which case one will expect 5.55 years of completed education). School attendance is in the order of $96 \%$, not far from universal although - as shown below - this masks substantial heterogeneity across age groups. On average, mothers have completed 10 years of schooling and the mean age at birth is 29 .

In Table 2, we report the proportion of children attending primary school or above and the distribution of completed school grades at each age. ${ }^{3}$ Children can enroll in the first grade of primary education if they become 6 before the $10^{\text {th }}$ of May of the school year (March -December) they intend to start. Thus, because ECH is collected continuously and no information on birth date is available we concentrate on the months of January to April of the survey for the completed

\footnotetext{
${ }^{3}$ There are 4 observations for children aged 7 attending preschool. School attendance and years of preschool completed are set to zero for them.
} 
school grade statistics. ${ }^{4}$ If enrollment in primary school were timely (at age 6) and transition from grade to grade were normal in Uruguay, children aged 7 during the interview months of January to April should have completed 1 year of education. However, 10\% of them have not completed any education at this point. This problem aggravates as children become older. For example, $21 \%$ of the children are lagging behind at age 9 . The first row of the table also illustrates rapidly growing drop out rates from age 12 onwards. While until age 11 school attendance is almost universal (99\%), at age 12 this is $98 \%$ and by age 16 this is in the order of $85 \%$.

In Table 3, we document the rapid rise in preschool attendance across subsequent birth cohorts. Here we report the coefficients of a regression of a dummy for preschool attendance on birth cohort dummies. In the first column we include no additional controls and in the second column we condition on household fixed effects. In practice, the latter investigates the growth in preschool attendance of siblings born in different years. Standard errors are heteroskedasticty consistent. The OLS estimates in column (1) show a pronounced trend in preschool attendance across cohorts. Preschool attendance grows by 17 percentage points between those born in 1985 (the omitted group) and those born in 1998. Results are qualitatively similar if one examines the fixed effect estimates in column (2). If anything, point estimates are slightly smaller in magnitude. This indicates that differences between subsequent cohorts partly reflect unobserved differences in "household quality": younger children are more likely to be born in households where the probability of attending preschool is higher. One explanation for this might be the secular rise in women's education, so that mothers of younger children are on average more educated, which at the same time might be correlated with higher preschool enrollment.

Although these results show a secular rise in preschool attendance in the population at large, they also mask substantial heterogeneity across different households. As already mentioned the reform was apparently extremely successful in incorporating children from less disadvantaged

\footnotetext{
${ }^{4}$ In the regression exercises that follow we address this problem by conditioning on month of the survey.
} 
backgrounds. Columns (3) and (4) check for this by reporting the same regressions as in columns (1) and (2) where now the cohort dummies are interacted with a dummy for mother's low education. We define a poorly educated mother as one with at most compulsory education (9 years of education). 52\% of children in the sample have mothers with at most compulsory education so by this criterion we roughly split the sample into two equally sized groups. Column (3) shows that children of poorly educated mothers start from lower enrollment. For the 1985 cohort this difference is in the order of 14 percentage points. As time goes by, an increasing proportion of children are incorporated into the preschool system. This is true for both groups of children. However the data reveal a significant catching up among children of poorly educated mothers starting with the 1991 cohort, i.e. the cohort supposedly entering pre-primary school (at age 5) in 1996. Notice that this is exactly the first cohort who should have benefited from the infrastructure expansion. The same pattern is found when we condition for household fixed effects, although differences between the two groups are generally smaller.

In sum, consistent with the evidence from administrative data, the ECH data confirm a strong delay in school progression among urban children and teenagers and a substantial school drop out before completion of compulsory schooling. We also find that, in the face of a generalized upward trend in preschool attendance, acceleration took place among children from less disadvantaged backgrounds (proxied by those whose mother has at most compulsory education). The timing of this acceleration is remarkably consistent with the implementation of the reform.

\section{Specification and identification}

In this section we devise an empirical strategy aimed at estimating the impact of preschool exposure on later school outcomes using simple regression tools. In order to do so we compare the school trajectories of children and teenagers who attended preschool to those who did not attend. Later on 
in the paper we investigate whether there is any evidence of differential returns from additional years of preschool education.

For this purpose we regress school outcomes of child $i$ of age $a$ in household $j\left(Y_{i a j}\right)$ on a dummy variable $\left(P S_{i}\right)$ for whether child $i$ attended at least one year of preschool, unrestricted age dummies $d_{a}$ and interactions of the two, plus a vector of observed child's characteristics $\left(X_{i}\right)$ and household characteristics $\left(X_{j}\right)$, including cohort effects that are common to all children born in the same year and time effects that are common to all children observed in the same year:

$$
Y_{i a j}=\beta_{0}+\beta_{1 a} P S_{i}+d_{a}+X_{i}^{\prime} \beta_{3}+X_{j}^{\prime} \beta_{4}+\varepsilon_{i a j}
$$

The parameters $\beta_{1 a}$ in equation (1) measure the effect of attending at least one year of preschool on school performance at age $a$ while $\beta_{3}$ and $\beta_{4}$ measure the correlation between individual and household characteristics and school outcomes.

Notice that the regressions presented below include in addition to dummies for a child's age, time dummies and birth cohort dummies (subsumed in the vector $X_{i}$ ), so that we measure progression relative to individuals born in the same year and observed at the same point in time but with different exposure to treatment. ${ }^{5}$ This allows us to control for changing aggregate conditions (e.g. country-wise trends in promotion policies or changes in the school curricula that affected children born in the same year equally) as well as differences across individuals of different ages (e.g. differences in the survival probability over the school cycle) that could induce some spurious correlation between the treatment and the outcomes variables, in turn leading to erroneous inference on the effect of preschool exposure on school outcomes.

In practice, though, even conditional on cohort, age and time effects, a simple comparison of children with different exposure to preschool is unlikely to lead to a consistent estimate of the effect of interest. As hinted at in the introduction there are good reasons to suspect that the correlation between school performance and preschool attendance picks up more than the causal effect of the

\footnotetext{
${ }^{5}$ Though, given the constraint that time $=$ cohort + age, the cohort effects can only be identified up to a linear trend.
} 
latter variable on the former. Parental education, levels of permanent income and wealth, family background and tastes, parents' labor force status, neighborhood characteristics - just to quote a few- are all likely to affect both the probability of attending preschool and later progression in school. For example, more educated parents might have a preference or the ability to afford preschool education of their children while at the same time promoting their academic achievement. If such family factors affect positively both variables, simple OLS estimates of school progression on preschool exposure are likely to lead to upward biased estimates of the effect of interest.

In order to attempt to circumvent this problem, in this paper we suggest comparing the differential school progression of siblings who happened to experience different exposure to preschool. As a variant of model (1) hence we present alongside estimates of the effect of preschool where we subsume any unobserved household characteristics that are common to all children in a household by including household fixed effects in the model $\mu_{j}$ :

$$
Y_{i a j}=\beta_{0}+\beta_{1 a} P S_{i}+d_{a}+X_{i}^{\prime} \beta_{3}+\mu_{j}+\varepsilon_{i a j}
$$

Model (2) estimates the effect of preschool exposure at each age by comparing siblings with different preschool histories. One can use differences in outcomes between a couple of siblings of different ages who either both attended or both did not attend preschool to identify the age effects (the $d_{a}$ 's). One can identify the effect of preschool exposure at different ages (the $\beta_{1 a}$ 's) by attributing to preschool exposure any residual differences in outcomes between an otherwise identical pair of siblings with different preschool histories.

If conditional on age, time and cohort effects, any spurious correlation between preschool exposure and latent school outcomes can be attributed to family characteristics that are common across siblings, then model (2) will lead to consistent estimates of the treatment effect.

Before turning to the empirical estimates, it is worth emphasizing where the variation in preschool exposure across siblings is originated in our data. Table 3 makes this point quite clearly. As said, the table shows that the cohort profiles in preschool attendance differ across children from 
different socio-economic backgrounds, these being much more pronounced for children from more disadvantaged backgrounds. If one is willing to assume that the cohort (and age and time) profiles in latent school outcomes (equations (1) and (2)) are the same for all children independent of their socio-economic background, this guarantees that sufficient intra-cohort variation is left (across socio-economic groups) to warrant identification of the parameters of the model.

\section{Regression results}

\subsection{Preschool attendance and stay-on rates}

We start by analyzing stay-on rates of individuals aged 7-16. Following model (1), in Table 4 we regress a dummy equal one if the individual is currently enrolled in school on a dummy for preschool attendance whose effect we allow to vary by age. We additionally include a number of controls. In addition to age dummies, in column (1) we condition on gender, cohort dummies, birth order dummies, and dummies for mother's age at birth plus dummies for the interactions between year, month of interview, and province. In column (2) we add years of education completed by the mother and its square to the previous set of controls. Finally, in Column (3) we introduce household fixed effects. ${ }^{6}$ Standard errors in this all and other regressions are heteroskedasticty consistent.

Column (1) illustrates a significant positive effect of preschool on school enrollment that grows monotonically with age. While at age 7 the difference in enrollment between treated and untreated individuals is in the order of 5 percentage points, by age 16 this difference is in the order of 24 percentage points.

As said, it might be the case that years of preschool education completed are correlated with household traits that also determine years of completed education. In column (2) we find some

\footnotetext{
${ }^{6}$ Two studies before us analyze the effect of preschool attendance on subsequent school progression among Uruguayan children. ANEP (2001) analyzes a panel of 268 children who attended pre-primary education since the ages of 4 or 5 and follows them up to first grade. ANEP (2005) uses administrative data from the Evaluación Nacional de Aprendizaje en el primer nivel de la escolaridad plus survey data from the education module of $2001 \mathrm{ECH}$. Both studies find a significant positive effect of preschool attendance on promotion rates and school progression. Differently from us these studies only analyze the short term effects of preschool and ignore the potential endogeneity of treatment.
} 
evidence for this hypothesis. Once we condition for mother's education differences at early ages tend to disappear, suggesting that family background partly explains the differences in column (1). Still, by age 16 differences between treated and untreated children are in the order of 22 percentage points, only slightly lower than the effect found in column (1).

When household fixed effects are included in column (3) differences in preschool attendance tend to become insignificant at most ages below age 13. After that we find again evidence of a considerable increase in attendance rates. By age 16, this difference is in the order of 27 percentage points, higher than the OLS estimate but not statistically distinguishable from it.

\subsection{Preschool attendance and educational achievement}

Although we have documented that preschool attendance is associated to a higher stay-on rate among teenagers, little is known about the effect of the treatment on actual educational achievement. In principle a higher stay-on rate does not necessarily imply more years of completed education if this is associated to a higher failure rate.

In columns (4) to (6) we present estimates of models (1) and (2) where we now measure school outcomes as the maximum grade completed. In the regressions we include both children who have already dropped out of school and those who are still in school, for whom the variable 'maximum grade completed' is right censored. Column (4), where only basic controls are included, shows that by age 8 children that attended preschool have already accumulated 0.15 more years of education compared to those who did not attend preschool. Again differences grow monotonically with age, so that by age 16, treated individuals have 1.13 extra years of education compared to non-treated individuals. When we control for mother's education in column (5) results are similar. Although estimates are slightly smaller in level, the gradient with respect to age is similar to the one found in column (4). In both cases the estimates imply that the difference in completed years of education 
between treated and untreated children grows by 0.13 for each additional year of age. Results with household fixed effects in column (6) are again very similar. ${ }^{7}$

Finally, note that among young children (ages 7-12), for whom preschool affects only marginally stay-on rates, our estimates provide essentially a measure of the effect of treatment on age-grade distortion (overage). This is simply the opposite of the effects reported in columns (4) to (6). If one takes the household fixed effect regressions, these imply that by age 12 children who did not attend preschool have accumulated already a third of a year of delay. From age 13 onwards our estimates mix the delay among those still in school plus the effect of drop out, both of which tend to depress completed education among untreated individuals.

From these simple estimates it is not obvious why the OLS estimates appear so remarkably similar to the within household estimates. One interpretation is that household unobserved characteristics affecting latent school performance are uncorrelated with exposure to preschool. However, the evidence in Table 3 suggests that this is unlikely to be the case, since children of poorly educated mothers show a significant lower level of preschool enrollment. One alternative explanation is that children in households warranting identification in the fixed effect estimator, i.e. those displaying sibling's variability in preschool attendance, also display relatively higher returns to preschool. Recall that these relatively more disadvantaged households. Omission of parental characteristics leads to downward biased estimates of the effect of interest while the variation among "compliers" leads to a treatment effect that is larger than the one to be found in the population at large. These two sources of bias possibly tend to compensate each other. ${ }^{8}$

\footnotetext{
${ }^{7}$ If anything -treated individuals - appear to start school slightly later than non preschoolers. This is evident from the fact that at age 7 the effect of preschool on completed education is negative, although only significant in column (4). Possibly there is an incentive for early enrollment in primary school among children who do not attend preschool. In this sense, our estimates of preschool attendance also encompass the indirect effect of starting primary school at a slightly later age. If higher entry age into primary school leads to better school performance, then our estimates will mix the direct effect of preschool attendance with the indirect (but apparently small) effect mediated via late entry.

${ }^{8}$ A very similar argument is used in the literature on return to human capital where most of the instruments for education used lead to IV estimates that are above the OLS estimates (see Card, 1999).
} 


\subsection{Effects at the intensive margin}

So far we have constrained the effect of preschool to be the same independently of the years of preschool attended. To investigate whether there are additional returns to extra years of preschool, we have re-estimated the regressions in Table 4, where we now allow the effect of treatment to vary for different years of preschool (1, 2 and 3). Rather than reporting a table with 21 different effects (i.e., 7 age groups times 3 possible years of preschool) we present these results in graphs. In Figures 1 and 2 we report separate graphs for the effect of attending at least 1 year, at least 2 years and 3 years. So, the first row of each graph gives the effect at the extensive margin, the second row gives the additional effect of attending 2 or more years compared to 1 year and the third row gives the additional effect of attending 3 years compared to attending 2. In the left hand side column we present estimates derived from a model where we condition on gender, age dummies, cohort dummies, birth order dummies, and dummies for mother's age at birth plus a dummies for the interactions between year, month of interview, and province (as in columns (1) and (4) of Table 4). In the right hand side column we add household fixed effects (as in columns (3) and (6) of Table 4). In both cases we report 95\% confidence intervals around the point estimates.

In Figure 1, we look at the effect of additional years of preschool on school attendance. The biggest effect of the treatment on school attendance rates is due to attendance at the extensive margin (having attended versus not having attended). There is a small additional effect from having attended a second year of preschool that shows up after age 12. There is a little evidence of gains from a third year of preschool. Results are remarkably robust to the inclusion of household fixed effects, although this is largely due to the circumstance that the point estimates become less precise and the confidence intervals become wider.

In Figure 2 we look at how the intensity of treatment affects years of schooling completed. Similarly to Figure 1 the largest effect is at the extensive margin with an impact that increases with age. When we do not condition on household fixed effects statistically significant effects at the 
intensive margin are found. This suggests a monotonic relationship between years of preschool and completed schooling. However, once we condition on household fixed effects, this additional effects disappear indicating that they are a consequence of a spurious correlation between household traits and years of preschool attended.

\subsection{Differences by gender}

Recent US evidence shows systematically larger medium and long-term benefits for girls compared to boys following early interventions in the form of pre-school (Anderson, 2006). This evidence is largely based on small experimental samples. In this section, we study whether any differences by gender in the gains from preschool education emerge in the Uruguayan context. In Table 5, we estimate separate regressions for males and females. For brevity we only report results with household fixed effects and we concentrate on the effects at the extensive margin. Identification here is warranted by households with at least two children of the same sex and with differential exposure to preschool. Although it appears that boys happen to benefit from preschool exposure at an earlier age than girls, by age 16 point estimates for boys and girls are very similar in magnitude and cannot be told statistically apart. Contrary to the US evidence, we find no indication of larger effects for girls. If anything, the opposite is true in Uruguay.

\subsection{Public versus private schooling}

One potential threat to the validity of our estimates is migration of students from the private to the public school system associated with increased preschool attendance. Because typically the expansion of pre-primary places came through the addition of preschool classrooms to existing public primary school, one possible explanation for our findings is that such expansion created incentives for children to remain in the public school system. If progression rates systematically 
differ between private and public schools and, in particular, if promotion rates are higher in public schools, this might explain the results found above.

To check for this we examine whether attendance to a public school is associated with exposure to preschool education. This exercise serves the additional purpose of checking for the validity of the identification assumption underlying the consistency of the within estimator, namely that household fixed effects wash out any spurious correlation between preschool exposure and latent school outcomes. Although this identification assumption is ultimately untestable with our data, the existence of some correlation between public school attendance and pre-school exposure across siblings would be raise some concern.

In Table 6, we regress a public school attendance dummy on age interacted dummies for preprimary education. Column (1), where basic controls are included, reveals a clear negative correlation between public school attendance and previous exposure to pre-primary school. It is plausible that this correlation is largely explained by the circumstance that better-off children are both more likely to attend a private school and to have attended preschool. This is confirmed in column (2) where we condition on mother's education. Results are still negative but not significant (except in one case). Once we include a household fixed effect in column (3) the effects tend to become smaller and again not significant. In sum, the results give little support to then notion that preschool exposure affects the decision to attend a public versus a private institution later in the school life.

\section{Discussion and conclusions}

This paper uses micro data from the Uruguayan Encuesta Continua de Hogares (ECH) to study the short and medium term effects of preschool attendance on school progression among children aged 7-16. We use a rather unique feature of the data that collects retrospective information on the number of years of preschool attended to estimate the impact of this variable on school stay-on rates 
and the number of school years completed. A major challenge in identifying the causal effect of preschool exposure on subsequent school progression stems from the difficulty of distinguishing between unobserved heterogeneity - whereby better-off children are both more likely to attend preschool and to perform better in school - and state dependence, that is the effect of interest. In order to control for household unobserved heterogeneity we compare school progression of siblings with different exposure to preschool. To the extent that most of the heterogeneity in preschool exposure and school performance comes from household characteristics that are common to all siblings, this strategy leads to consistent estimates of the effect of interest.

Our results show a significant positive effect of preschool attendance on the number of years of schooling completed since very early ages. Already by age 10 treated individuals show an advantage in terms of completed education in the order of 0.28 years. As time goes on, the difference in achievement between children who attended preschool and those who did not increases, and the two groups follow eventually starkly diverging paths. By age 12, treated individuals have accumulated around 0.32 years more of education compared to non-treated individuals. Although we have no way to identify in our data the precise mechanism through which small initial differences tend to be exacerbated as children grow older, one explanation is that the initial penalty suffered by children who did not attend preschool gets compounded by the state dependency in grade repetition. Early grade failure may lower expectations and induce disenfranchisement among children, their households or teachers. If the (assumed) remedial effect of grade failure is small or not existent, early grade failure may worsens children's later school progression inducing further grade failure and explaining the diverging paths found in this paper.

The effect of exposure to pre-primary education is long lasting. Starting from age 13 we find significant evidence that untreated individuals are more likely to drop out of school compared to treated individuals. By age 16 children who attended preschool are 27 percentage points more likely to be in school and have accumulated more than one extra year of education. Because our 
observations are right censored given that most children are still in school by age 16, these are presumably conservative estimates of the effect of preschool on completed education. Finally, because most of the variation used to identify the effect of interest stems from children from more disadvantaged background one has to be cautious in extrapolating these results to the population at large. Nevertheless, the effect of pre-primary expansion on the most disadvantaged households is likely to be the parameter of main interest in the evaluation of public policy. 


\section{References}

Anderson, M. (2006), Uncovering Gender Differences in the Effects of Early Intervention: A Reevaluation of the Abecedarian, Perry Preschool, and Early Training Projects, mimeo, MIT Department of Economics, April 2006.

ANEP (1997), Programa de Educación Inicial para 3, 4 y 5 años, ANEP-MECAEP, Montevideo, 1997 (available at http://www.mecaep.edu.uy/docs/PEI.pdf)

ANEP, (2000), Una visión integral del Proceso de Reforma Educativa en Uruguay 1995-1999, Montevideo, 2000.

ANEP, (2001), Estudio de evaluación de impacto de la educación inicial en Uruguay, Montevideo, 2001 (available at http://www.mecaep.edu.uy/docs/EEIEIU.pdf).

ANEP, (2005), Panorama de la educación en el Uruguay, Una década de transformaciones. 19922004, Monetevideo, 2005 (available at http://www.anep.edu.uy/gerenciagrl/ger_inv_eva/ publicaciones/Panorama_de_la_educuc_Uruguay.htm).

Barnett, S., (1993), "Benefits of Compensatory Pre-school Education”, Journal of Human Resources, 279-312.

Barnett, S., (1995), "Long-Term Effects of Early Childhood Programs on Cognitive and School Outcomes", The Future of Children, 25-50.

Barro, R. J. and Jong-Wha Lee , (2001), "International Data on Educational Attainment: Updates and Implications", Oxford Economic Papers, 3, 541-563.

Berlinski, S., S. Galiani and P. Gertler, (2006), “The effect of pre-primary education on primary school performance”, IFS working paper, W06/04.

Blau, D.M. and J. Currie, (2004), "Pre-school, Day Care, and After School Care: Who’s Minding the Kids?” NBER Working Paper, \# 10670, Cambridge MA.

Bransford, J.D., (1979), Human Cognition: Learning, Understanding, and Remembering, Wadsworth.

Card, D., (1999), "The Causal Effect of Schooling on Earnings,” in O. Ashenfelter and D. Card, eds., Handbook of Labor Economics, Amsterdam, Elsevier.

Carneiro, P. and J. Heckman, (2003), "Human Capital Policy”, in J. Heckman and A. Krueger, eds., Inequality in America: What role for human capital policies?, Boston, MIT Press.

Cascio, E., (2004), "Schooling Attainment and the Introduction of Kindergartens into Public Schools", mimeo.

Cunha, F., J. Heckman, L. Lochner, and D. Masterov, (2006), "Interpreting the Evidence on Life Cycle Skill Formation”, forthcoming in E. Hanushek and F. Welch, eds., Handbook of the Economics of Education, Amsterdam, Elsevier.

CIA, (2005),World Factbook 2005 (available at http://www.cia.gov/cia/publications/factbook)

Currie, J. and D. Thomas, (1995), “Does Head Start Make a Difference?”, American Economic Review, 85, 341-364.

Currie, J. and D. Thomas, (1999), “Does Head Start Help Hispanic Children?”, Journal of Public Economics 74, 235-262.

Currie, J., (2001), "Early Childhood Education Programs”, Journal of Economic Perspectives 15, 213-238.

Danziger, S. and J. Waldfogel, (2000), Securing the Future: Investing in Children from Birth to College, Russell Sage Foundation.

Duflo, E., (2001), "Schooling and Labor Market Consequences of School Construction in Indonesia: Evidence from an Unusual Policy Experiment”, American Economic Review,91, 795-813. 
Garces, E., D. Thomas and J. Currie, (2002), "Longer-Term Effects of Head Start”, American Economic Review, 92, 999-1012.

Heckman, J., J. Stixrud and S. Urzua, (2006), “The Effects of Cognitive and Non-Cognitive Skills on Labor Market Outcomes and Social Behavior”, NBER Working Paper \# 12006, Cambridge MA.

IMF, (2005), WORLD ECONOMIC OUTLOOK Database, September 2005, (available at http://www.imf.org/external/pubs/ft/weo/2005/02/data/index.htm)

Karoly, L. et al., (1998), Investing in our Children: What we Know and Don't Know about the Costs and Benefits of Early Childhood Interventions, Santa Monica: RAND.

Maddison, A., (2004), The World Economy Historical Statistics, Organization for Economic Cooperation and Development, 2004. (available at http://www.ggdc.net/Maddison/).

Magnuson, A., C. Ruhm, and J. Waldfogel, (2005), "Does Prekindergarten Improve School Preparation and Performance?", Economics of Education Review, forthcoming.

Manacorda, M. (2006), "Grade Failure, Drop out and Subsequent School Outcomes: QuasiExperimental Evidence from Uruguayan Administrative Data”, mimeo, Centre for Economic Performance, LSE January 2006.

Myers, R., (1995), "Pre-school Education in Latin America: Estate of Practice", PREAL Working Papers No. 1.

OECD, (2002), "Strengthening Early Childhood Programs: A Policy Framework", in Education Policy Analysis, Paris.

Reynolds, A., (1998), "Extended Early Childhood Intervention and School Achievement: Age Thirteen Findings from the Chicago Longitudinal Study”, Child Development, 69, 231-246.

Rimm-Kaufman, S., R. Pianta and M. Cox, (2000), "Teachers' judgments of problems in the transition of kindergarten”, Early Childhood Research Quarterly, 15, 147-166.

Schweinhart, L. J., J. Montie, Z. Xiang., W.S. Barnett, C. R. Belfield, M. Nores, (2005), “Lifetime effects: The High/Scope Perry Pre-school study through age 40”, Monographs of the High/Scope Educational Research Foundation 14.

Shonkoff, J. and D. Phillips (eds.), (2000), From Neurons to Neighborhoods: The Science of Early Childhood Development, National Academy Press, Washington D.C.

Shore, R., (1997), Re-thinking the Brain: New Insights into Early Development, Families and Work Institute, New York.

Sternberg, R., (1985), Beyond IQ: A Triarchic Theory of Human Intelligence, Cambridge University Press.

UNESCO , (2005), EFA Global Monitoring Report. (Data available at: http://portal.unesco.org).

Urquiola, M. and V. Calderon, (2004), “Apples and oranges: Educational enrolment and attainment across countries in Latin America and the Caribbean”, mimeo, Department of Economics, Columbia University, 2004. 
Figure 1. The Effect of Additional Years of Preschool on School Attendance by Age

a. Without Household Fixed Effects

1 year of preschool

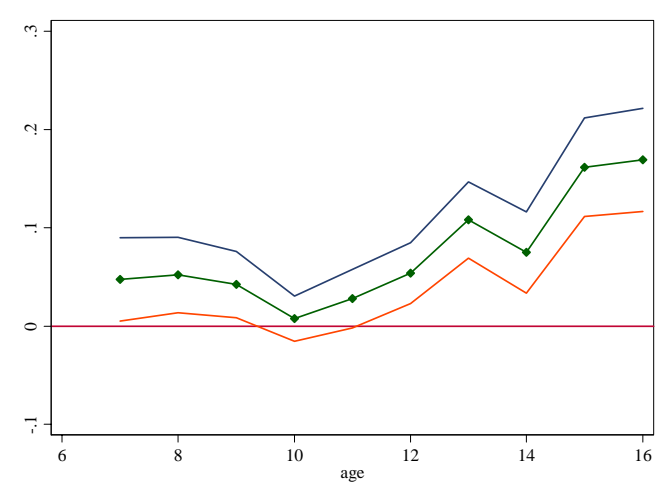

2 years of preschool

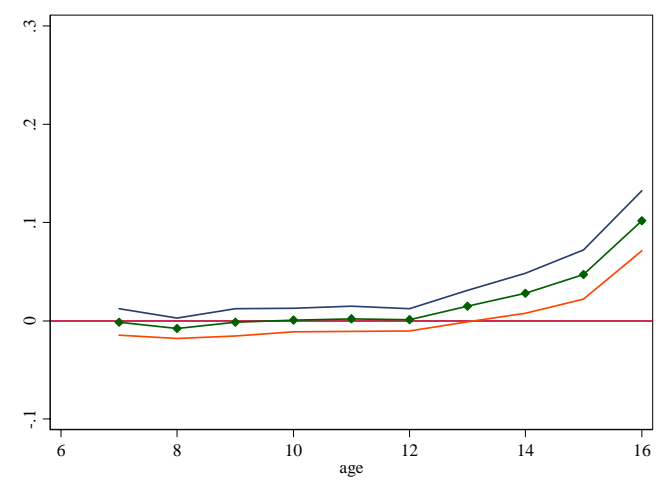

3 years of preschool

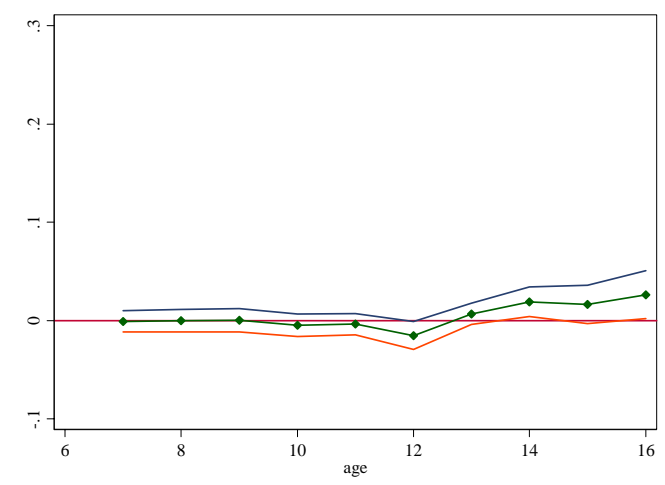

b. With Household Fixed Effects

1 year of preschool

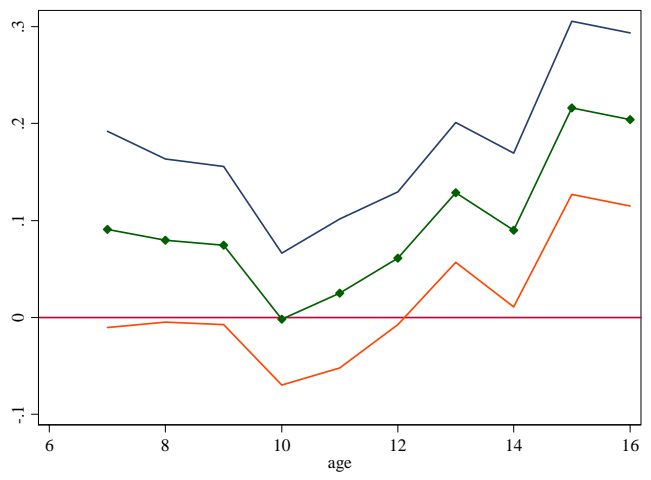

2 years of preschool

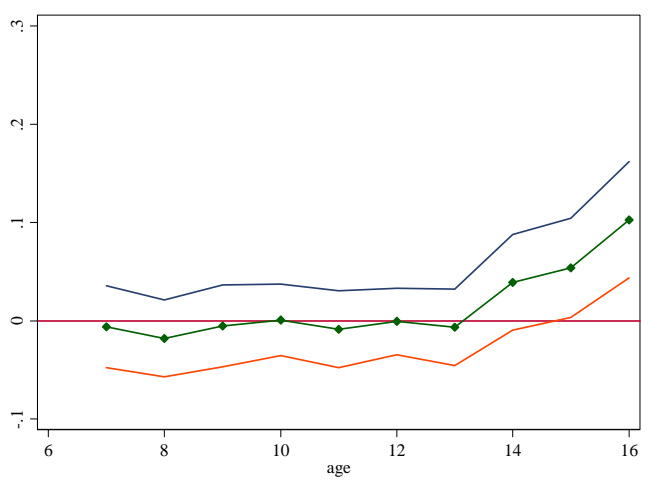

3 years of preschool

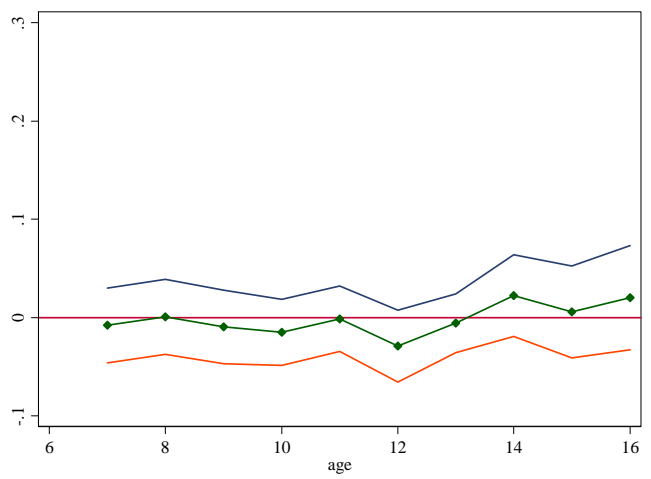

Source: Own calculations based on Encuesta Continua de Hogares 2001-2005.

Notes: The graph reports the estimated effect of each additional year of preschool on school attendance. In columns a. and b., respectively, we condition on the same variables as in columns (1) and (3) of Table 4. 95\% confidence intervals around the estimated effects are also reported. 
Figure 2. The Effect of Additional Years of Preschool on Years of Schooling Completed by Age

a. Without Household Fixed Effects

1 year of preschool

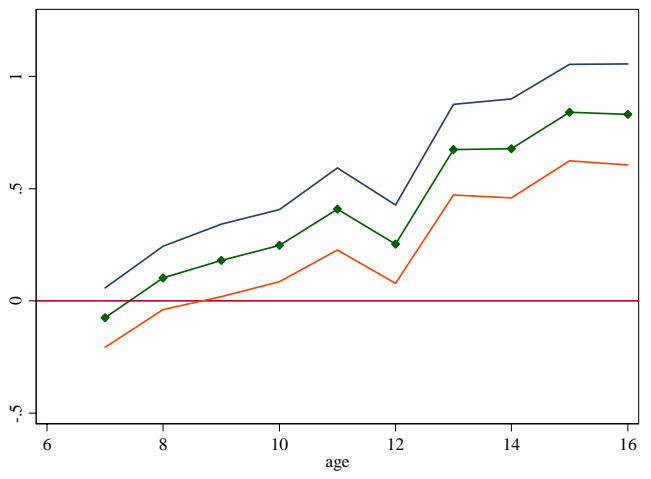

2 years of preschool

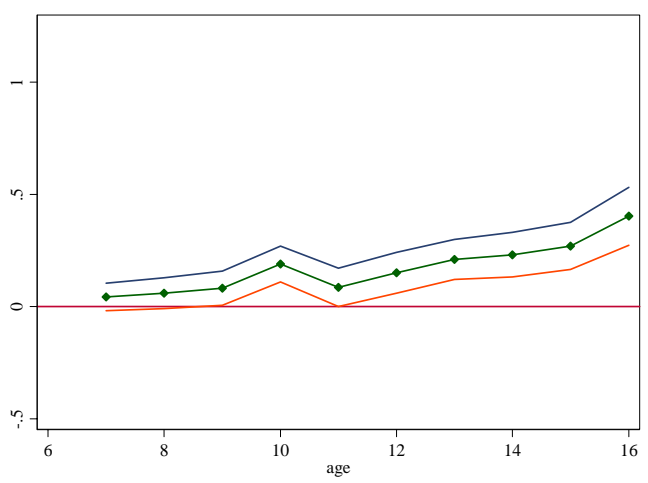

3 years of preschool

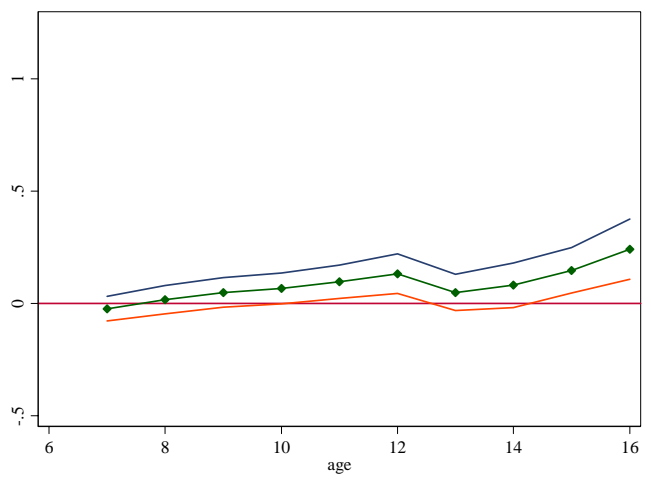

b. With Household Fixed Effects

1 year of preschool

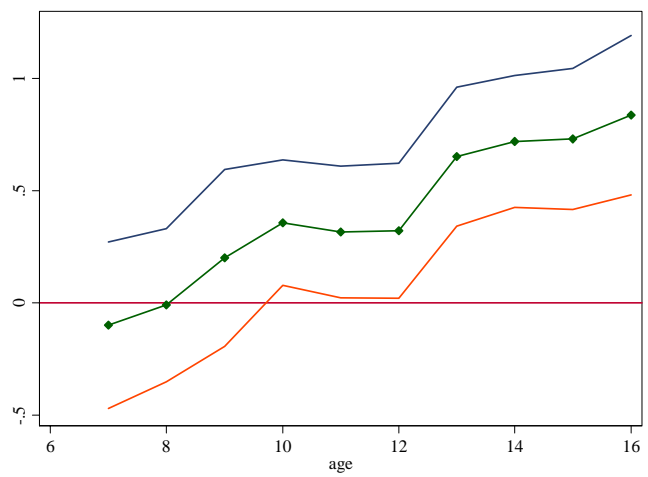

2 years of preschool

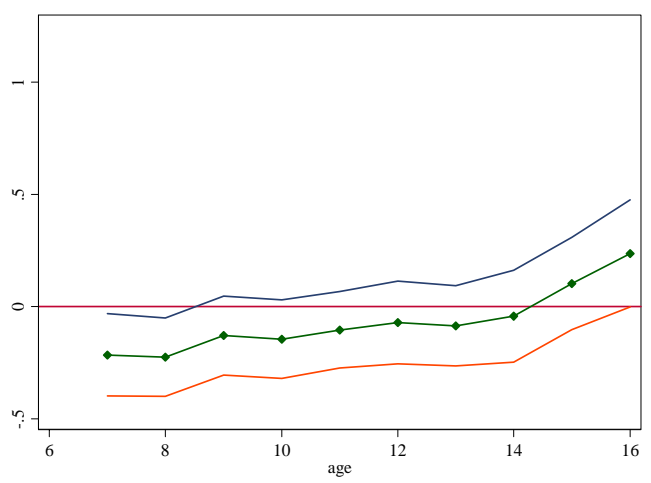

3 years of preschool

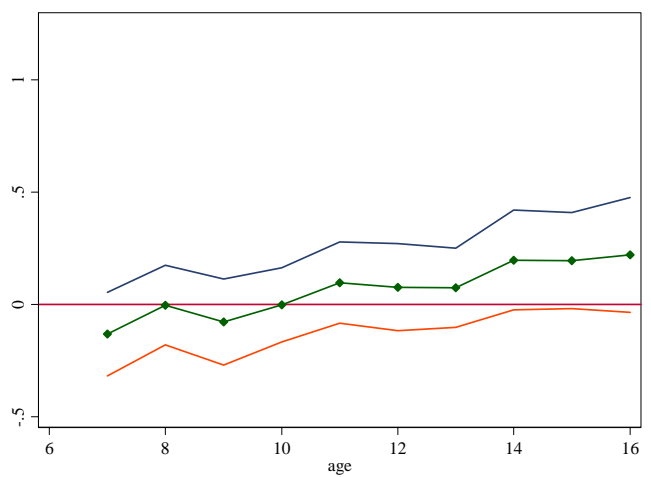

Source: Own calculations based on Encuesta Continua de Hogares 2001-2005.

Notes: The graph reports the estimated effect of each additional year of preschool on years of schooling completed. In columns a. and b., respectively, we condition on the same variables as in columns (4) and (6) of Table 4. 95\% confidence intervals around the estimated effects are also reported. 
Table 1. Definition and Description of Variables

\begin{tabular}{|c|c|c|c|c|c|}
\hline Variable & Description of Variables & Mean & Std. Dev. & Min. & Max. \\
\hline Preschool Education & $\begin{array}{l}\text { Years of preschool education completed as retrospectively reported by } \\
\text { parents of children age } 7 \text { to } 16 \text {. }\end{array}$ & 1.74 & 0.91 & 0 & 3 \\
\hline Attended 1, 2 or 3 years of preschool & $=1$ for children that attended 1, 2 or 3 years of preschool and 0 otherwise. & 0.90 & & 0 & 1 \\
\hline Years of Preschool = 2 & $=1$ for children that attended 2 of preschool and 0 otherwise. & 0.39 & & 0 & 1 \\
\hline Years of Preschool $=3$ & $=1$ for children that attended 3 years of preschool and 0 otherwise. & 0.22 & & 0 & 1 \\
\hline Years of Schooling & $\begin{array}{l}\text { Years of primary and secondary schooling completed for children age } 7 \text { to } 16 \\
7 \text { to } 14 \text {. }\end{array}$ & 5.03 & 2.80 & 0 & 9 \\
\hline School Attendance & = 1 for children currently attending primary or above school and 0 otherwise. & 0.96 & & 0 & 1 \\
\hline Public School & $=1$ for children that attend public schools and 0 otherwise. & 0.82 & & 0 & 1 \\
\hline Age & Child age. In the regression analysis we use 9 age dummies. & 11.55 & 2.84 & 7 & 16 \\
\hline Cohort & Birth cohort. Defined as survey year minus age. & & & 1985 & 1996 \\
\hline Female & $=1$ if the child is female and 0 otherwise. & 0.49 & & 0 & 1 \\
\hline Birth Order & $\begin{array}{l}\text { Birth order among all cohabitating children. In the regression analysis } \\
\text { we use } 6 \text { birth order dummies. }\end{array}$ & 1.92 & 1.11 & 1 & 7 \\
\hline Mother's Age at Birth & $\begin{array}{l}\text { Age of the mother at birth. In the regression analysis we use } 9 \text { age } \\
\text { group dummies. }\end{array}$ & 28.52 & 6.20 & 12 & 51 \\
\hline Schooling of the Mother & Years of completed education of the mother. & 9.83 & 3.95 & 0 & 23 \\
\hline Low Mother's Education & $=1$ if mother's education is less or equal to 9 years and 0 otherwise. & 0.52 & & 0 & 1 \\
\hline Year & Year of Interview. In the regression analysis we use 4 year dummies. & & & 2001 & 2005 \\
\hline Month & Month of Interview. In the regression analysis we use 11 month dummies. & & & 1 & 12 \\
\hline Province & $\begin{array}{l}\text { Departamento where the child lives. In the regression analysis we use } \\
18 \text { dummies. }\end{array}$ & & & 1 & 19 \\
\hline Observations & & \multicolumn{4}{|c|}{25,696} \\
\hline
\end{tabular}

Source: Own calculations based on Encuesta Continua de Hogares 2001-2005. 
Table 2. School Progression: School Attendance and Years of Schooling Completed by Age (in percentages).

\begin{tabular}{|c|c|c|c|c|c|c|c|c|c|c|}
\hline \multicolumn{11}{|c|}{ Age } \\
\hline & 7 & 8 & 9 & 10 & 11 & 12 & 13 & 14 & 15 & 16 \\
\hline School Attendance & 98.51 & 98.84 & 98.51 & 98.86 & 98.59 & 98.21 & 96.38 & 94.89 & 91.10 & 85.74 \\
\hline 0 Years of Schooling & 9.83 & 2.21 & 0.37 & 0.00 & 0.36 & 0.23 & 0.52 & 0.12 & 0.11 & 0.36 \\
\hline 1 Years of Schooling & 73.91 & 10.92 & 3.73 & 1.37 & 0.00 & 0.00 & 0.42 & 0.12 & 0.11 & 0.12 \\
\hline 2 Years of Schooling & 16.26 & 69.80 & 17.27 & 5.61 & 2.63 & 1.28 & 1.04 & 1.09 & 0.44 & 0.48 \\
\hline 3 Years of Schooling & 0.00 & 17.07 & 62.36 & 15.46 & 4.18 & 1.16 & 0.63 & 0.36 & 0.11 & 0.00 \\
\hline 4 Years of Schooling & 0.00 & 0.00 & 16.27 & 63.12 & 14.70 & 5.12 & 2.40 & 0.61 & 0.22 & 0.24 \\
\hline 5 Years of Schooling & 0.00 & 0.00 & 0.00 & 14.43 & 65.59 & 19.07 & 6.67 & 2.91 & 0.99 & 0.48 \\
\hline 6 Years of Schooling & 0.00 & 0.00 & 0.00 & 0.00 & 12.54 & 57.33 & 17.73 & 11.02 & 7.17 & 8.45 \\
\hline 7 Years of Schooling & 0.00 & 0.00 & 0.00 & 0.00 & 0.00 & 15.81 & 54.85 & 17.07 & 9.70 & 7.62 \\
\hline 8 Years of Schooling & 0.00 & 0.00 & 0.00 & 0.00 & 0.00 & 0.00 & 15.75 & 51.21 & 18.74 & 11.55 \\
\hline 9 Years of Schooling & 0.00 & 0.00 & 0.00 & 0.00 & 0.00 & 0.00 & 0.00 & 15.50 & 52.37 & 19.64 \\
\hline 10 Years of Schooling & 0.00 & 0.00 & 0.00 & 0.00 & 0.00 & 0.00 & 0.00 & 0.00 & 9.81 & 41.07 \\
\hline 11 Years of Schooling & 0.00 & 0.00 & 0.00 & 0.00 & 0.00 & 0.00 & 0.00 & 0.00 & 0.11 & 9.76 \\
\hline 12 Years of Schooling & 0.00 & 0.00 & 0.00 & 0.00 & 0.00 & 0.00 & 0.00 & 0.00 & 0.11 & 0.12 \\
\hline 13 Years of Schooling & 0.00 & 0.00 & 0.00 & 0.00 & 0.00 & 0.00 & 0.00 & 0.00 & 0.00 & 0.12 \\
\hline
\end{tabular}

Source: Own calculations based on Encuesta Continua de Hogares 2001-2005.

Note: The information on Years of Schooling is based only on data from the months of January to April. 
Table 3. Pre-Primary Education and School Cohort

\begin{tabular}{|c|c|c|c|c|}
\hline & \multicolumn{4}{|c|}{ Dependent variable: Attended 1, 2 or 3 Years of Preschool } \\
\hline & $(1)$ & $(2)$ & $(3)$ & $(4)$ \\
\hline \multirow[t]{2}{*}{ Cohort $=1986$} & 0.057 & 0.027 & 0.061 & 0.026 \\
\hline & {$[0.020]^{\star \star \star}$} & [0.025] & {$[0.023]^{\star \star \star}$} & [0.028] \\
\hline \multirow[t]{2}{*}{ Cohort $=1987$} & 0.046 & 0.030 & 0.027 & 0.021 \\
\hline & {$[0.019]^{\star \star}$} & [0.024] & [0.023] & [0.028] \\
\hline \multirow[t]{2}{*}{ Cohort $=1988$} & 0.053 & 0.036 & 0.034 & 0.037 \\
\hline & {$[0.019]^{\star \star \star}$} & [0.023] & [0.022] & [0.027] \\
\hline \multirow[t]{2}{*}{ Cohort = 1989} & 0.054 & 0.035 & 0.029 & 0.014 \\
\hline & {$[0.018]^{\star \star \star}$} & [0.023] & {$[0.022]$} & {$[0.027]$} \\
\hline \multirow[t]{2}{*}{ Cohort $=1990$} & 0.078 & 0.055 & 0.053 & 0.048 \\
\hline & {$[0.018]^{\star \star \star}$} & {$[0.023]^{\star \star}$} & {$[0.021]^{\star \star}$} & {$[0.028]^{\star}$} \\
\hline \multirow[t]{2}{*}{ Cohort = 1991} & 0.090 & 0.070 & 0.055 & 0.042 \\
\hline & {$[0.018]^{\star \star \star}$} & {$[0.023]^{\star \star \star}$} & {$[0.021]^{\star \star \star}$} & [0.028] \\
\hline \multirow[t]{2}{*}{ Cohort = 1992} & 0.096 & 0.094 & 0.053 & 0.051 \\
\hline & {$[0.018]^{\star \star \star}$} & {$[0.023]^{\star \star \star}$} & {$[0.021]^{\star \star}$} & {$[0.028]^{\star}$} \\
\hline \multirow[t]{2}{*}{ Cohort = 1993} & 0.118 & 0.096 & 0.080 & 0.053 \\
\hline & {$[0.018]^{\star \star \star}$} & {$[0.024]^{\star \star \star}$} & {$[0.021]^{\star \star \star}$} & {$[0.028]^{\star}$} \\
\hline \multirow[t]{2}{*}{ Cohort = 1994} & 0.124 & 0.109 & 0.077 & 0.055 \\
\hline & {$[0.018]^{\star \star \star}$} & {$[0.024]^{\star \star \star}$} & {$[0.021]^{\star \star \star}$} & {$[0.028]^{\star}$} \\
\hline \multirow[t]{2}{*}{ Cohort = 1995} & 0.139 & 0.119 & 0.080 & 0.057 \\
\hline & {$[0.018]^{\star \star \star}$} & {$[0.024]^{\star \star \star}$} & {$[0.021]^{\star \star \star}$} & {$[0.029]^{\star \star}$} \\
\hline \multirow[t]{2}{*}{ Cohort = 1996} & 0.136 & 0.131 & 0.084 & 0.060 \\
\hline & {$[0.018]^{\star \star \star}$} & {$[0.025]^{\star \star \star}$} & {$[0.021]^{\star \star \star}$} & {$[0.030]^{\star \star}$} \\
\hline \multirow[t]{2}{*}{ Cohort = 1997} & 0.163 & 0.139 & 0.105 & 0.071 \\
\hline & {$[0.018]^{\star \star \star}$} & {$[0.026]^{\star \star \star}$} & {$[0.021]^{\star \star \star}$} & {$[0.031]^{\star *}$} \\
\hline \multirow[t]{2}{*}{ Cohort = 1998} & 0.166 & 0.157 & 0.108 & 0.086 \\
\hline & {$[0.019]^{\star \star *}$} & {$[0.033]^{\star \star \star}$} & {$[0.021]^{\star \star \star}$} & {$[0.037]^{\star *}$} \\
\hline \multirow[t]{2}{*}{ Low Mother's Education } & & & -0.140 & \\
\hline & & & {$[0.033]^{\star \star \star}$} & \\
\hline \multirow[t]{2}{*}{ Low Mother's Education $\times$ Cohort = 1986} & & & 0.002 & 0.001 \\
\hline & & & [0.038] & [0.047] \\
\hline \multirow[t]{2}{*}{ Low Mother's Education $\times$ Cohort $=1987$} & & & 0.037 & 0.014 \\
\hline & & & {$[0.037]$} & [0.046] \\
\hline Low Mother's Education $\times$ Cohort $=1988$ & & & 0.039 & -0.005 \\
\hline & & & [0.036] & [0.044] \\
\hline Low Mother's Education $\times$ Cohort $=1989$ & & & 0.046 & 0.031 \\
\hline & & & [0.035] & [0.044] \\
\hline Low Mother's Education $\times$ Cohort $=1990$ & & & 0.048 & 0.008 \\
\hline & & & {$[0.035]$} & {$[0.044]$} \\
\hline Low Mother's Education $\times$ Cohort $=1991$ & & & 0.066 & 0.045 \\
\hline & & & {$[0.035]^{*}$} & [0.045] \\
\hline Low Mother's Education $\times$ Cohort $=1992$ & & & 0.082 & 0.069 \\
\hline & & & {$[0.035]^{\star *}$} & [0.044] \\
\hline Low Mother's Education $\times$ Cohort $=1993$ & & & 0.073 & 0.069 \\
\hline & & & {$[0.034]^{\star \star}$} & [0.045] \\
\hline Low Mother's Education $\times$ Cohort $=1994$ & & & 0.090 & 0.088 \\
\hline & & & {$[0.034]^{\star \star \star}$} & {$[0.045]^{\star}$} \\
\hline Low Mother's Education $\times$ Cohort $=1995$ & & & 0.112 & 0.100 \\
\hline & & & {$[0.034]^{\star \star \star}$} & {$[0.046]^{\star *}$} \\
\hline Low Mother's Education $\times$ Cohort $=1996$ & & & 0.097 & 0.118 \\
\hline & & & {$[0.035]^{\star \star \star}$} & {$[0.048]^{\star *}$} \\
\hline Low Mother's Education $\times$ Cohort $=1997$ & & & 0.110 & 0.113 \\
\hline & & & {$[0.035]^{\star \star \star}$} & {$[0.050]^{\star \star}$} \\
\hline Low Mother's Education $\times$ Cohort $=1998$ & & & 0.107 & 0.118 \\
\hline & & & {$[0.037]^{\star \star \star}$} & {$[0.064]^{*}$} \\
\hline Observations & 25,696 & 25,696 & 25,696 & 25,696 \\
\hline & & Specifica & cludes: & \\
\hline Household dummies & No & Yes & No & Yes \\
\hline
\end{tabular}

Source: Own calculations based on Encuesta Continua de Hogares 2001-2005.

Notes: OLS regression. Omitted category: Birth Cohort of 1985. For the definition of control variables see Table 1.

Robust standard errors in brackets. * significant at 10\%; ** significant at 5\%; ${ }^{\star \star \star}$ significant at $1 \%$. 
Table 4.The Impact of Preschool Attendance on School Attendance and Years of Schooling Completed

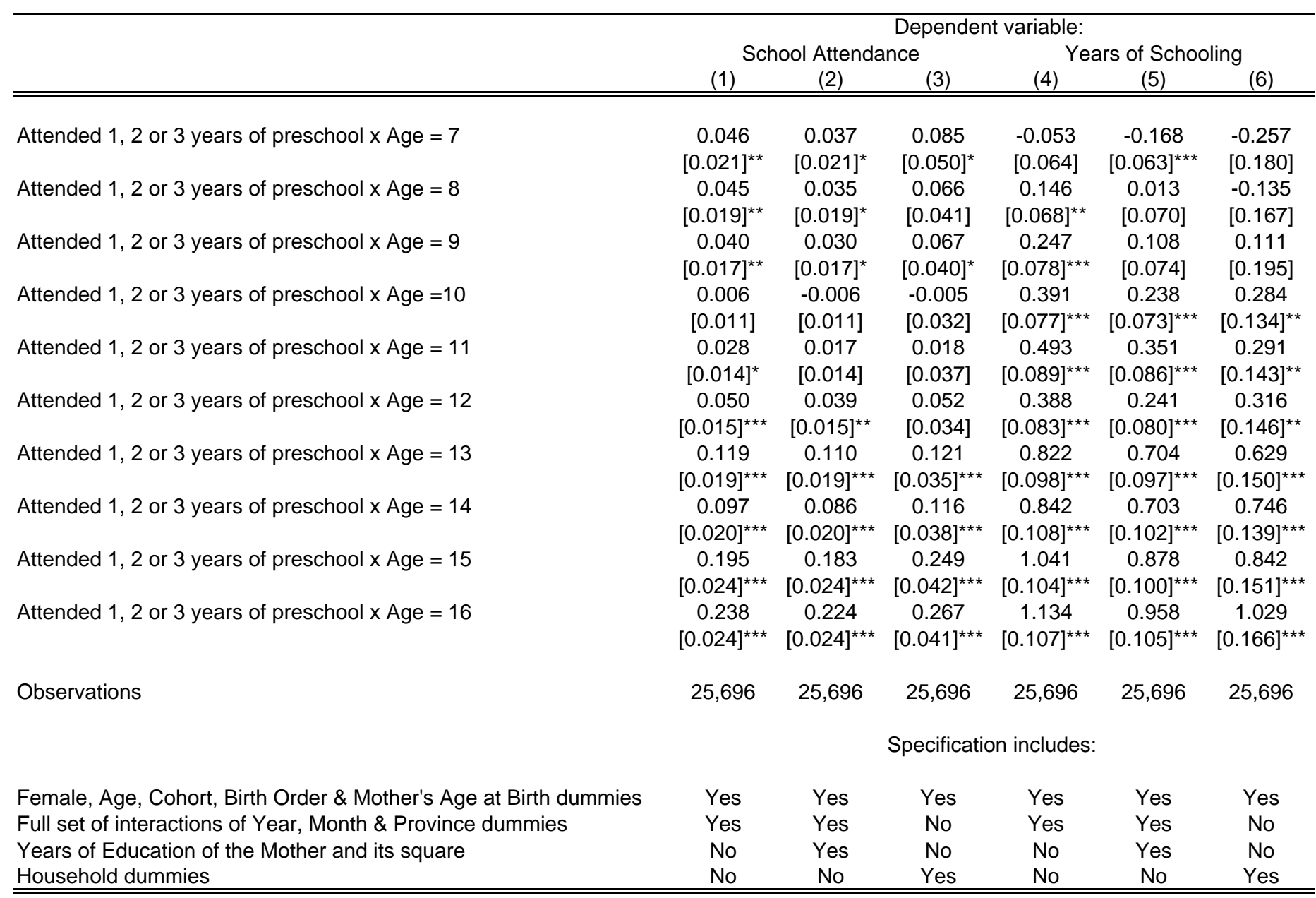

Source: Own calculations based on Encuesta Continua de Hogares 2001-2005.

Notes: OLS regression. For the definition of variables see Table 1. Robust standard errors in brackets. * significant at $10 \%$; *夫

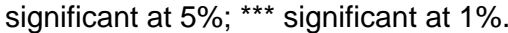


Table 5.The Impact of Preschool Attendance on School Attendance and Years of Schooling Completed.

Separate regressions by gender.

\begin{tabular}{|c|c|c|c|c|}
\hline & \multicolumn{4}{|c|}{ Dependent variable: } \\
\hline & \multicolumn{2}{|c|}{ School Attendance } & \multicolumn{2}{|c|}{ Years of Schooling } \\
\hline & $\begin{array}{c}\text { Male } \\
(1)\end{array}$ & $\begin{array}{c}\text { Female } \\
(2)\end{array}$ & $\begin{array}{c}\text { Male } \\
(3) \\
\end{array}$ & $\begin{array}{c}\text { Female } \\
(4)\end{array}$ \\
\hline Attended 1,2 or 3 years of preschool $\times$ Age $=7$ & $\begin{array}{c}0.134 \\
0.1099\end{array}$ & $\begin{array}{c}0.135 \\
0.0991\end{array}$ & $\begin{array}{l}-0.206 \\
\end{array}$ & $\begin{array}{l}-0.066 \\
\end{array}$ \\
\hline Attended 1,2 or 3 years of preschool $\times$ Age $=8$ & $\begin{array}{c}0.049 \\
{[0.087]}\end{array}$ & $\begin{array}{c}0.068 \\
{[0.107]}\end{array}$ & $\begin{array}{l}-0.072 \\
{[0.341]}\end{array}$ & $\begin{array}{c}0.000 \\
{[0.445]}\end{array}$ \\
\hline Attended 1, 2 or 3 years of preschool $\times$ Age $=9$ & $\begin{array}{c}0.031 \\
{[0.096]}\end{array}$ & $\begin{array}{c}0.107 \\
{[0.069]}\end{array}$ & $\begin{array}{c}0.062 \\
{[0.392]}\end{array}$ & $\begin{array}{c}0.360 \\
{[0.389]}\end{array}$ \\
\hline Attended 1,2 or 3 years of preschool $\times$ Age $=10$ & $\begin{array}{l}-0.028 \\
{[0.066]}\end{array}$ & $\begin{array}{l}-0.028 \\
{[0.077]}\end{array}$ & $\begin{array}{c}0.205 \\
{[0.293]}\end{array}$ & $\begin{array}{c}0.451 \\
{[0.303]}\end{array}$ \\
\hline Attended 1,2 or 3 years of preschool $\times$ Age $=11$ & $\begin{array}{c}0.042 \\
{[0.084]}\end{array}$ & $\begin{array}{c}0.002 \\
{[0.083]}\end{array}$ & $\begin{array}{c}0.582 \\
{[0.297]^{\star \star}}\end{array}$ & $\begin{array}{c}0.243 \\
{[0.338]}\end{array}$ \\
\hline Attended 1,2 or 3 years of preschool $\times$ Age $=12$ & $\begin{array}{c}0.084 \\
{[0.068]}\end{array}$ & $\begin{array}{c}0.005 \\
{[0.074]}\end{array}$ & $\begin{array}{c}0.574 \\
{[0.321]^{\star}}\end{array}$ & $\begin{array}{c}0.235 \\
{[0.335]}\end{array}$ \\
\hline Attended 1,2 or 3 years of preschool $\times$ Age $=13$ & $\begin{array}{c}0.160 \\
{[0.082]^{\star}}\end{array}$ & $\begin{array}{c}0.100 \\
{[0.085]}\end{array}$ & $\begin{array}{c}0.720 \\
{[0.337]^{\star \star}}\end{array}$ & $\begin{array}{c}0.559 \\
{[0.375]}\end{array}$ \\
\hline Attended 1,2 or 3 years of preschool $\times$ Age $=14$ & $\begin{array}{c}0.202 \\
{[0.096]^{\star \star}}\end{array}$ & $\begin{array}{c}0.078 \\
{[0.076]}\end{array}$ & $\begin{array}{c}1.011 \\
{[0.305]^{\star \star \star}}\end{array}$ & $\begin{array}{c}0.716 \\
{[0.319]^{\star \star}}\end{array}$ \\
\hline Attended 1,2 or 3 years of preschool $\times$ Age $=15$ & $\begin{array}{c}0.352 \\
{[0.089]^{\star \star \star}}\end{array}$ & $\begin{array}{c}0.203 \\
{[0.095]^{\star \star}}\end{array}$ & $\begin{array}{c}1.024 \\
{[0.329]^{\star \star \star}}\end{array}$ & $\begin{array}{c}0.749 \\
{[0.325]^{\star \star}}\end{array}$ \\
\hline Attended 1,2 or 3 years of preschool $\times$ Age $=16$ & $\begin{array}{c}0.363 \\
{[0.090]^{\star \star \star}}\end{array}$ & $\begin{array}{c}0.247 \\
{[0.110]^{\star \star}}\end{array}$ & $\begin{array}{c}1.348 \\
{[0.362]^{\star \star \star}}\end{array}$ & $\begin{array}{c}1.406 \\
{[0.530]^{\star \star \star}}\end{array}$ \\
\hline Observations & 13,137 & 12,559 & 13,137 & 12,559 \\
\hline & & Specificatic & on includes: & \\
\hline Female, Age, Cohort, Birth Order \& Mother's Age at Birth dummies & Yes & Yes & Yes & Yes \\
\hline Full set of interactions of Year, Month \& Province dummies & Yes & Yes & No & Yes \\
\hline Years of Education of the Mother and its square & No & Yes & No & No \\
\hline Household dummies & No & No & Yes & No \\
\hline
\end{tabular}

Source: Own calculations based on Encuesta Continua de Hogares 2001-2005.

Notes: OLS regression. For the definition of variables see Table 1. Robust standard errors in brackets. *

significant at $10 \%$; ** significant at $5 \%$; *** significant at $1 \%$. 
Table 6.The Impact of Preschool Attendance on Public School Attendance

\begin{tabular}{|c|c|c|c|}
\hline \multirow{3}{*}{ Attended 1,2 or 3 years of preschool $\times$ Age $=7$} & \multicolumn{3}{|c|}{$\begin{array}{c}\text { Dependent variable: } \\
\text { Public School Attendance }\end{array}$} \\
\hline & $(1)$ & $(2)$ & $(3)$ \\
\hline & $\begin{array}{l}-0.031 \\
{[0.033]}\end{array}$ & $\begin{array}{c}0.018 \\
{[0.030]}\end{array}$ & $\begin{array}{c}0.032 \\
{[0.029]}\end{array}$ \\
\hline Attended 1,2 or 3 years of preschool $\times$ Age $=8$ & $\begin{array}{c}-0.086 \\
{[0.028]^{\star \star \star}}\end{array}$ & $\begin{array}{l}-0.028 \\
{[0.027]}\end{array}$ & $\begin{array}{c}0.003 \\
{[0.030]}\end{array}$ \\
\hline Attended 1,2 or 3 years of preschool $\times$ Age $=9$ & $\begin{array}{c}-0.077 \\
{[0.028]^{\star \star \star}}\end{array}$ & $\begin{array}{c}-0.031 \\
{[0.024]}\end{array}$ & $\begin{array}{c}0.014 \\
{[0.018]}\end{array}$ \\
\hline Attended 1,2 or 3 years of preschool $\times$ Age $=10$ & $\begin{array}{c}-0.064 \\
{[0.023]^{\star \star *}}\end{array}$ & $\begin{array}{l}-0.001 \\
{[0.020]}\end{array}$ & $\begin{array}{l}-0.005 \\
{[0.022]}\end{array}$ \\
\hline Attended 1,2 or 3 years of preschool $\times$ Age $=11$ & $\begin{array}{c}-0.121 \\
{[0.021]^{\star * *}}\end{array}$ & $\begin{array}{c}-0.065 \\
{[0.019]^{\star * *}}\end{array}$ & $\begin{array}{l}-0.003 \\
{[0.021]}\end{array}$ \\
\hline Attended 1,2 or 3 years of preschool $\times$ Age $=12$ & $\begin{array}{c}-0.079 \\
{[0.021]^{\star \star \star}}\end{array}$ & $\begin{array}{l}-0.023 \\
{[0.019]}\end{array}$ & $\begin{array}{c}0.011 \\
{[0.015]}\end{array}$ \\
\hline Attended 1,2 or 3 years of preschool $\times$ Age $=13$ & $\begin{array}{c}-0.076 \\
{[0.020]^{\star \star \star}}\end{array}$ & $\begin{array}{l}-0.021 \\
{[0.018]}\end{array}$ & $\begin{array}{c}0.003 \\
{[0.014]}\end{array}$ \\
\hline Attended 1,2 or 3 years of preschool $\times$ Age $=14$ & $\begin{array}{c}-0.077 \\
{[0.021]^{\star \star \star}}\end{array}$ & $\begin{array}{l}-0.014 \\
{[0.018]}\end{array}$ & $\begin{array}{c}0.014 \\
{[0.018]}\end{array}$ \\
\hline Attended 1,2 or 3 years of preschool $\times$ Age $=15$ & $\begin{array}{c}-0.055 \\
{[0.018]^{\star \star \star}}\end{array}$ & $\begin{array}{c}0.01 \\
{[0.016]}\end{array}$ & $\begin{array}{l}-0.001 \\
{[0.015]}\end{array}$ \\
\hline Attended 1,2 or 3 years of preschool $\times$ Age $=16$ & $\begin{array}{c}-0.061 \\
{[0.018]^{\star \star *}}\end{array}$ & $\begin{array}{c}0.017 \\
{[0.016]}\end{array}$ & $\begin{array}{c}0.041 \\
{[0.018]^{\star *}}\end{array}$ \\
\hline Observations & 25,650 & 25,650 & 25,650 \\
\hline
\end{tabular}

Specification includes:

Female, Age, Cohort, Birth Order \& Mother's Age at Birth dummies Full set of interactions of Year, Month \& Province dummies

Years of Education of the Mother and its square

Yes Yes Yes

Household dummies

\begin{tabular}{lll} 
Yes & Yes & Yes \\
Yes & Yes & No \\
No & Yes & No \\
No & No & Yes \\
\hline
\end{tabular}

Source: Own calculations based on Encuesta Continua de Hogares 2001-2005

Notes: OLS regression. For the definition of variables see Table 1. Robust standard errors in

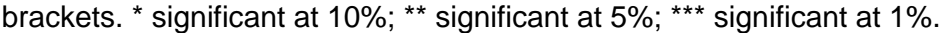

